\title{
Re-Thinking Loft Buildings in the Scope of Housing Production in Turkey*
}

\author{
Türkiye'de Konut Üretimi Kapsamında Loft Binaları Yeniden Düşünmek
}

\author{
Neslinur HIZLI, Burçin MIZRAK
}

\section{ABSTRACT}

In an age of rapid urbanization, the question of how housing should respond to increasing, changing demands of cities has become crucial. The aim of the present study was to re-envision the role of the loft building in housing production in Turkey in terms of responding to those needs, and to discuss loft buildings within the context of an open building-embodying adaptability, variability, and flexibility. To do so, literature was reviewed, and six examples, three national and three international, were analyzed. Two interviews were conducted, one with a member of a design team, and one with a user of loft examples. The study demonstrates that loft buildings embody the fundamentals of the open building concept, with high ceilings and structural systems that provide interior space without division, but which diverge from the concept due to restrictions in their facades. It also suggests that lofts can play a remarkable role in future Turkish housing production due to these open building characteristics.

Keywords: Loft buildings; open building; support and infill; user participation; the SAR system.

\section{Öz}

Hızlı kentleşmenin olduğu bir çağda, konutların, şehirlerin artan ve değişen ihtiyaçlarına nasıl cevap vereceği keşfedilmesi gereken önemli bir sorun olmaktadır. Bu bildiri, bu ihtiyaçlara cevap verebilmek açısından loft binaların konut üretimindeki yerini yeniden düşünmeyi ve loft binaları 'uyumluluk, değişebilirlik ve esneklik' kavramlarını da içinde barındıran 'açık yapı' konsepti üzerinden tartışmayı amaçlamaktadır. Bu amaçla, ilgili yazın taranmış ve üçü yurtiçi, üçü yurtdışından olmak üzere alt örnek analiz edilmiştir. Biri, örnek loft binamızın tasarım ekibinden, bir diğeri de kullanıcısı olmak üzere iki kişi ile röportaj yapılmıştır. Çalışma göstermiştir ki, loft binalar yüksek duvarları ve iç mekânı bölmeyen taşıyıcı sistemleriyle açık yapı konseptinin temel özelliklerini içinde barındırırken, cephedeki kısıtlamalardan dolayı konseptten ayrılmaktadır. Açık yapı karakteristiği ile Türkiye'nin gelecekteki konut üretiminde önemli bir rol oynamaktadır.

Anahtar sözcükler: Loft binalar; açık yapı, destek ve tamamlayıcı üniteler; kullanıcı katılımı; sar sistemi. *This article has been developed from the conference paper 'Re-Thinking Loft Buildings in the
Scope of the Dwelling Production in Turkey', originally presented at the International Environ-
ment and Design Conference in Istanbul, December 2014.
*Bu makale, 11-12 Aralık 2014 tarihinde Bahçeşehir Üniversitesi Mimarlık ve Tasarım Fakültesi ev sahipliğinde gerçekleşen Uluslararası Çevre ve Tasarım Kongresi'nde bildiri olarak sunulmuş olup, çalışmanın literatür kısmında verilen bilgiler yazarlar tarafından geliştirilmiştir.

Department of Architecture, Yildiz Technical University, İstanbul, Turkey.

Article arrival date: March 17, 2014 - Accepted for publication: November 02, 2015

Correspondence: Neslinur HIZLI. e-mail: neslinurhizli@hotmail.com 


\section{Introduction}

A dwelling has a mechanism, which is changing according to the culture, income, and demographic characteristics of users. If any of these factors of the users' changes, the dwelling must correspond to this. But when looking at today's dwelling production, quite monotonous dwelling groups are seen. Although architects or designers indicate that they really care about user-centered housing designs, the majority of the apartments only appeal to a score of people. Therefore, in this age of rapid urbanization, how the residential buildings should be and should react to the rapid increase in population and to the changing lifestyles of citizens in big cities are still the problems waiting to be solved.

Loft buildings, which were come up with converting idle industrial buildings to home/office buildings as an alternative solution to problem of homelessness of the 1970s in the United States also began to be implemented in Turkey gradually. This approach is considered as a new trend because, investors aim to provide new packages and facilities, for who will have a house in this period of rapid consumption of space and housing. So, will loft buildings be improved instead of monotonous housing architecture as an alternative in changing conditions? What kind of contribution do these buildings make in residential building sector of Turkey? The aim of the study is to re-think the importance of loft buildings in dwelling production in Turkey and to discuss loft buildings over the concept of open building; embodying adaptability, variability, and flexibility.

In this paper, before giving definitions and examination of loft examples; literature review, which includes open building discourses and the concept of flexibility, adaptability, variability, are given.

\section{Literature Review}

In our developing world, the increase of the needs of people and technological developments, which occur in line with these needs, affect changes and developments in society again. In the wake of these developments, our expectations about the future of structures, in which we keep living, also change. And that paradigm shift and the emergence of new arrangements in the existing structures lead to the motion of change and so give rise to the notion of 'variability'. Residential users' time-varying needs, demands and habits require taking some precautions at the planning stage. Besides the existing buildings adapting to new functions because of the new requirements, the assumption of possible future changes of to be con- structed buildings, make the concept of variability and flexibility important at the planning and design stage. The variability of the residential building means that the housing plan has a certain system and adaptation which provide alternative solutions to the users' changing and improving living conditions. Besides its definition which is mentioned in the Turkish Language Association as "susceptible to different interpretations", the word of 'flexible' is one of the different types of variability with its meaning like variable, addable, adaptable, expandable. Although these concepts have very similar meanings, they have major differences in terms of usage in architecture. Giving information about these concepts, which will be mentioned frequently in case studies, would be appropriate for better understanding of the study.

The Concept of Flexibility, Adaptability, Variability In Residential Buildings

The concept of flexibility in architecture can divide into various topics depending on the residential building's physical, mechanical and structural systems at the stage of planning, design and practice. This classification can change depending on the bearing elements i.e. built-in elements (columns, slabs, vertical installation shafts, vertical circulation elements) and variable parts (non-load bearing walls, plane of working, display elements). Ustun describes flexibility as a method, which is depending on principles of construction and distribution of service spaces. He explains that the main components of flexible scheme are pre-planned relations between the loadbearing axis, loadbearing interior partitions, central heating, water and electricity services, main and service spaces. Ustun also notes that the adaptability is based on basis of planning and organization. Room sizes, spatial relations between rooms, load bearing internal dividers, the perception of space regardless of function are the parameters of adaptation. ${ }^{1}$

The adaptability is to provide opportunity for reuse of residential space with a different function at any period of time. Obsolescence of function in residential space is a problem, decreasing the value of the building. The solution is changing use without changing structural components; in other words it is the principle of adaptability, which provides flexibility. The variability is to grow outward, to expand by way of modules. As it is understood from this point, the difference between adaptability and variability is the structural components coming into play and their ability to change.

1 Ustun, 2000. 
The concept of flexibility is, with the words of Tapan, ${ }^{2}$ the same design unit's ability of fulfilling the different users' requirements without changing structure system and is the opportunity to take advantage of the same volumes for multiple functions. The variability is the behavior, which requires changing the structure system for meeting the changing needs and actions' requirements. According to Yurekli, ${ }^{3}$ the purpose of giving insight into the flexibility percept to any space is having the opportunity for re-organization of spatial layout. Also, the renewal of mechanical equipment or its additions are important. According to $\mathrm{Ce}-$ tin, the purpose of the flexible design is to redound a future for building by meeting the changes in the organization, which emerge as a result of the integration of structural, physical and mechanical components. Cetin also mentions that there are two important points to keep in mind in flexible designs; first one is evaluating and thinking about the function's progress in the future; second is determining the fixed and variable areas correctly in not yet defined forms, and organizing correctly. He remarks the five main elements in flexible design; the lower non-load bearing sections, central heating, the framework of open building, pre-planned service spaces, external wall system. ${ }^{4}$

\section{Habraken's Flexible Housing; Support and Infill Units}

With John Habraken's own words, 'In its ordinary usage, flexibility denotes not only a physical change, modification or adaptation, for a variety of purposes or uses, but also freedom, which emerges as one of the key meanings. It as such also refers to adaptation, as well. ${ }^{5}$ Flexibility was first announced in the first half of $20^{\text {th }}$ century in industrialized European cities and offered alternative solutions. The production of mass housing lack of identity after the $2^{\text {nd }}$ World War under the strict norms of current authorities and their politics, led to the construction of monotonous housing examples. In 1960's, when these examples were examined, according to Bilgin, it is come up with the idea that the production of those houses with finished and determined architectural layouts resulted in the alienation of users to their own houses. ${ }^{6}$ As a solution to this alienation, Habraken suggested that the active participation of individuals and citizens to the design process of housing projects. Habraken also stated that through arranging the plan of their houses, occupants' personality could be expressed and seen. ${ }^{7}$

\footnotetext{
2 Tapan, 1972.

3 Yurekli, 1983

4 Cetin, 1999.
}

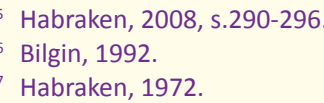

In the book 'Supports, an Alternative to Mass Housing', Habraken proposes the separation of 'support' (base building) from 'infill' (fit-out) in residential construction. One of the different hierarchical levels of the building section, fixed part i.e. support unit, has been used to determine the decisions made by society, while in-fill unit has been used to explain the decisions made by individuals. The permanent and long-lived support includes the service spaces and the structure of a building, while the infill which can be arranged by users' needs and preferences -and can be obtained through normal marketing channels- contains the variable units like facades, wet space walls, partition walls, installation components based cable and pipe, wallfloor-ceiling coverings. ${ }^{8}$ Under Habraken's directorship 'Stichting Architecten Research' (The SAR) ${ }^{9}$ group indicate that the architect's role is not to design housing, but it is to design the loadbearing system, in which housing will settle. In this system, spaces are variable within the framework of flexibility aspect in their allocated zones. In the system developed by SAR group, structural elements are considered as two groups; one is mobile and composed of variable elements, and the other is immobile and composed of loadbearing elements.

Between the years of 1965-1968, SAR and PSSHAK systems had provided different alternatives to users through incorporating them into the design at the stage of construction. According to changing needs during the usage, they had ensured the continuation of flexibility with attachable and detachable division elements. In particular, support and infill units being independent from each other physically and functionally have contributed greatly to development of variable residential practices. According to Doesburg, the design becomes a form of open building system with its no longer loadbearing walls and its decreasing loadbearing zones. In this open system, the whole structure, which is consisted of a single space, can be divided according to the demands and preferences when needed. The non-loadbearing division elements (inside) and the protective surfaces (outside) provide aforesaid partitions and the movable elements are divisional elements which separate spaces. ${ }^{10}$

In contrary to monotonous residential building with

\footnotetext{
8 Habraken, 1972.

9 The Dutch Foundation for Architectural Research (SAR) which investigated the use of industrial manufacturing in mass housing and looked at the role of archi-

tects within this, was established in 1965 as a research institute and remained active until the beginning of the 1990s.

${ }^{10}$ Deniz, 2003.
} 
Table 1. Four topics for Case Studies (edited by the authors)

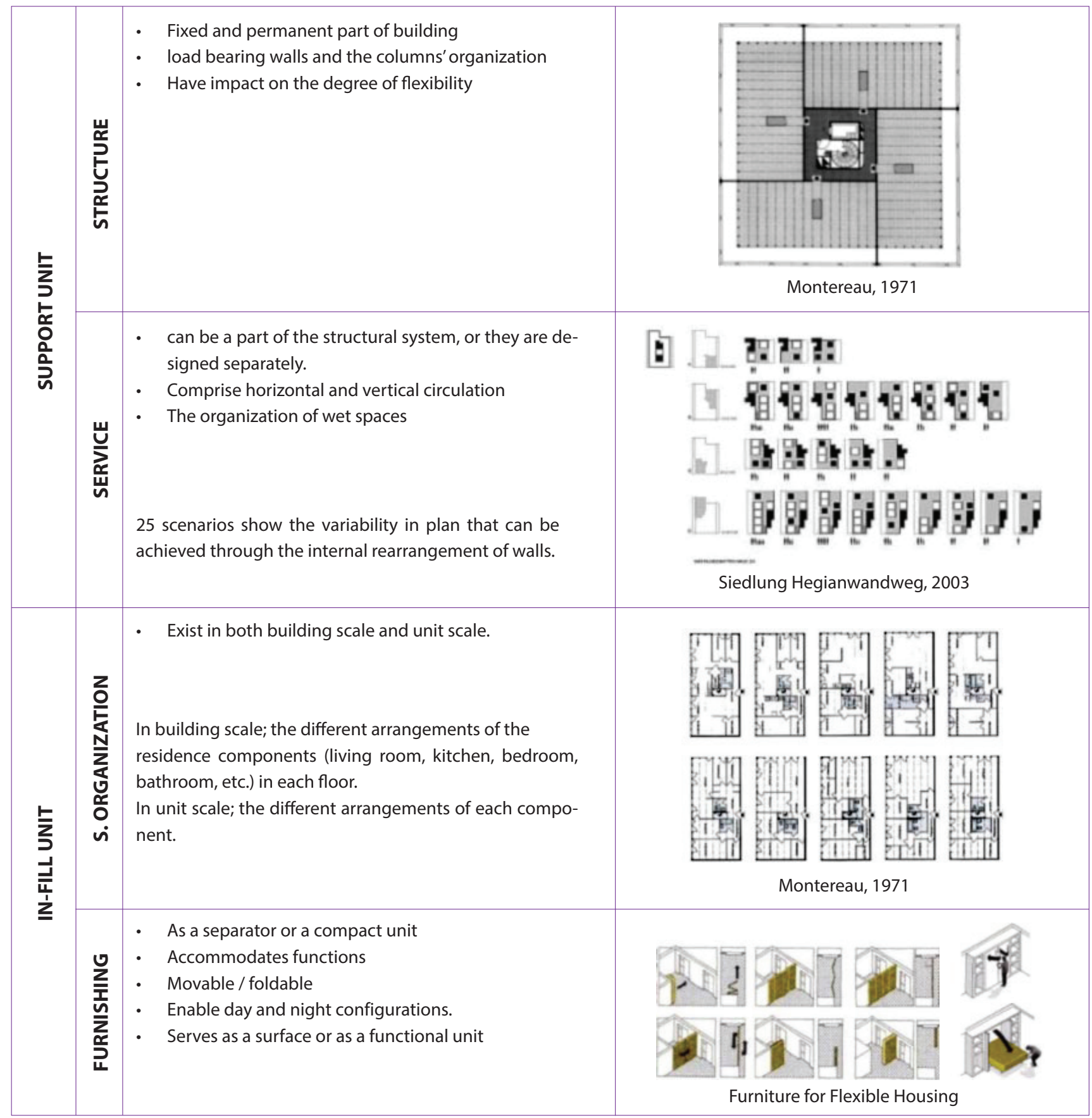

design principles of these units ${ }^{11}$ (support and infill) in "open building" system, thousands of dwelling production in Europe, in the States, in Japan and in China has been performed.

${ }^{11}$ Existing legal regulations in Turkey, in case of change during period of building usage, infill structure section (in independent housing units) doesn't pose an obstacle providing if certain requirements are fulfilled. (Construction Law, Property Ownership Law). Multi-user public space of a housing block, support unit should be designed by considering the properties of entire block users, common needs, building standards and regulations. Legal Regulation of Turkey, support structure areas and system are collected under the heading of 'common places'.

\section{Case Studies}

As it is seen from discourses there are number of ways achieving flexibility in residential building design. In this study, loft building examples (three international and three national) were analyzed on the basis of flexible housing systems through four main topics; Structure, Service, Spatial Organization, Furnishing (Table 1). With the purpose of study in mind, in addition to analyzing examples, two interviews were done. One is with the user of a loft 
flat and the other one is with the architect of a loft project. $^{12}$

\section{The Concept of Loft Building}

The definition of "loft" in Oxford dictionary is made as a room or space directly under the roof of a house or other building, used for accommodation or storage. However, after the de-industrialization movement started in 1950's in U.S.A. and in Western Europe, the word started to be used as a new housing typology independent of its lexical meaning. And, this new typology, developed from the conversion of ex-industrial buildings to the houses, was called loft too. This conversion occurred spontaneously at that time with the artists' attempts to try to live and work in those exindustrial buildings, because they're cheap and also suitable for the realization of artworks of all sizes. Until the 1970's, living in a loft was considered neither chic nor comfortable. ${ }^{13}$ In the context of this progress, there exist the social changes that occurred in respect to the de-industrialization of the economy, the post-industrial transition. However, in 70's ex-industrial buildings started to be perceived as more romantic than the post- industrial offices, apartments, and shopping centers. The middle-class consumers started to find "loft living" attractive. The decay of Western industrial regions since 1960's has been perceived by architects and urban planners with an increasing doubt on what the future of post-industrial settings will grasp. "Heritage" has been introduced as a new concept in the architectural discourse. It is no happenstance that the concept of "industrial heritage" emerged at approximately the same period that the industrial structure pervading and clasping western cities terminated to be the motivator of these cities. "The chance for things to age and to become ruin has diminished in the age of turbo capitalism." ${ }^{14}$ It was not only architects and urban planners but also the artists, photographers, filmmakers, etc., who accompanied this transition and contributed in a sense this gentrification process. Hilla and Bernd Becher, who spent decades recording the industrial heritage of the Ruhr region, published this work as a book (1970) called 'Anonymous Structures: A Typology of Technical Construction' and in this way they gave exceptional and unique aesthetic value to the industrial built structures.

\footnotetext{
${ }^{12}$ The user is Prof. Dr. Suha Ozkan who lives in Levent Loft and the architects are Sefer Caglar and Seyhan Özdemir from Autoban Architects. We posed our ques- 14 Huyssen, 2006. tions to them over mentioned
}

As it could be anticipated, the highest collaboration for SoHo as an artist settlement came from the liberal press, especially, the New York Times, the New York Post, and the Village Voice. Since 1961 till 1983, about 175 articles published in these publications expressing numerous parts and phases of loft conversion in lower Manhattan. There were inscriptions on varied subjects such as the political and practical problems of loft conversions; the new life-style in lofts, the art being produced, the lives of the artists; the new stores opening; and of course, restaurant reviews. ${ }^{15}$ The real estate market and the politics responded to this changing perception on unused buildings and consumption pattern. So, lofts have become a luxurious housing typology. In 1980's, loft living started to represent luxury with its rents changing between 300 and $600 \$ .{ }^{16}$ In 2000's loft-style housing typology promotion attempts have been resulted in the perception of living in open buildings with high ceilings as an indicator of new life-style, which is "loft life-style" (Figure 1a, b).

A conversion from an ex-industrial building was not even a requisite anymore. This new life-style was adapted by the members of upper middle class and high class. Above there are two photographs one from 1970's and the other from 2009. Both of them are conversion projects, however their concepts and status are totally different.

Whilst the primary artists have actually moved into SoHo's ex-industrial built structures because of their unordinary architectural characteristics and also low prices, Zukin exhibits in depth how the first lofts converted into studio apartments were achieved with the attempts of real estate developers and how they launched a newfangled housing typology through advertisement and standardization. ${ }^{17}$

The exhibition of Office for Metropolitan Architecture (OMA) in the 2010 Venice Biennale of Architecture was underlying this shift in the conservation and conversion of the unused built structures of the city. Their work was criticizing the ideologies of conservation, which privilege the exceptional over the typical and expressing an objection to the 'auteurist' transformation of buildings and heritage sites. So, as a first time, the architect was criticizing his role and his own work in the process.

\section{Loft concept in Turkey}

Turkey has not been undergone a change in parallel with industrialization process of $19^{\text {th }}$ century Europe,

\footnotetext{
${ }^{15}$ Hudson, 1987. $\quad{ }^{16}$ Russell, 1978.
} 

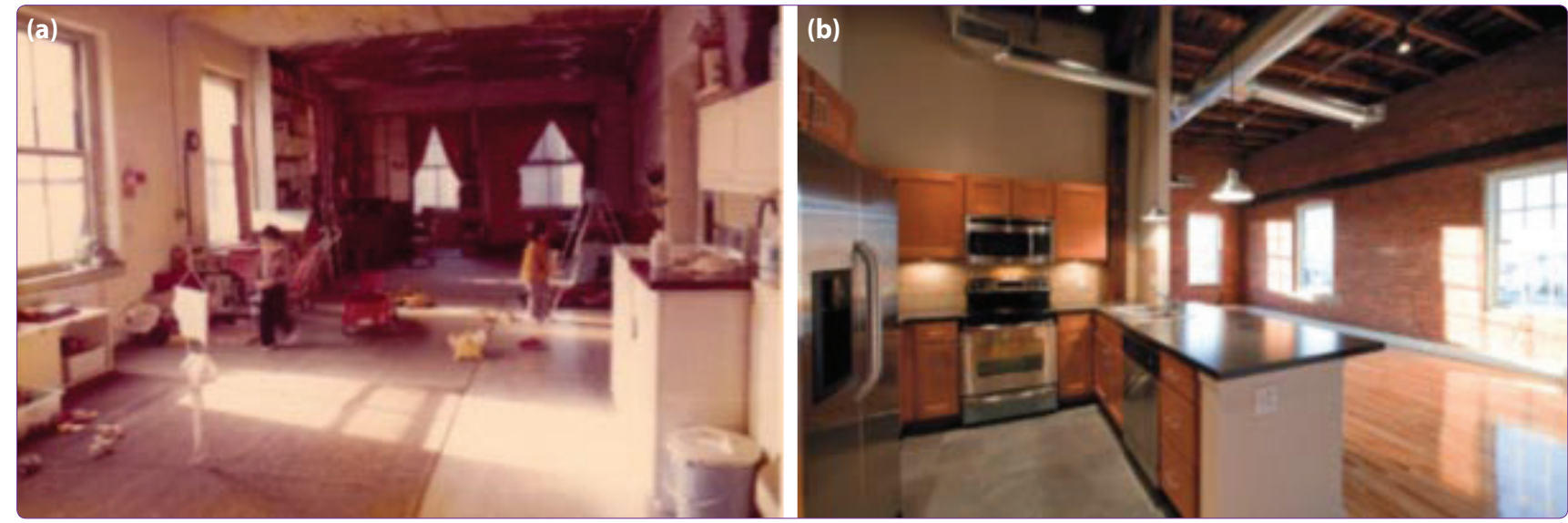

Figure 1. (a) A photograph from a Loft in the SoHo District in New York from 1970's rented for \$125/month; (b) Lancaster-based Drogaris Cos. developed the Swisher building, a $\$ 7.9$ million renovation. ([a] The Soho Memory Project, http://sohomemory.com/tag/history-of-soho/page/3/ [b] Central Penn Business Journal, http://www.cpbj.com/article/20110930/CPBJ01/110939969/Trendy-loft-dwellings-lift-downtown-economies)

since Ottoman Empire. There has been no significant transformation in mass-production until 1950s. The impact of industrialized countries on Turkey showed itself just in trade. ${ }^{18}$ As of Tanzimat reforms, there have been some changes began in industry at the end of the 19th century. Many factories were located in mainly Golden Horn, Bosphorus and Marmara Coast, while commercial offices, warehouse and banks were seen in mainly Galata and Beyoğlu district. ${ }^{19}$

In 19th century, suburban areas have become one of the most important places of Istanbul following the developments in transport system. Certain districtslocated on the both sides of the Bosphorus- Kadıköy, Bakırköy and Yeşilköy have been transformed to major suburban centers. These developments have led to changes on the Anatolian side; a commercial port in Haydarpaşa and gasworks in Hasanpaşa. ${ }^{20}$

Industrial buildings in Istanbul can be listed as big, medium-sized and small-atelier businesses in terms of production capacities, size and importance. Except this, there are also many buildings in the city which are part of production system and supporting industrial production but not located in the same field with their main production structure such as ateliers, stores and warehouses.

Economical discourse had been prevalent in Turkey from the beginning of 1980s, also affected industrial facilities in İstanbul as in every part of life and country. Industrial facilities founded in Ottoman Empire began to become non-functional in 1980s. The factors such as lack of the government's support for production of raw materials, production with few assortments and poor quality, deficiency of the use of domestic goods and fondness for foreign products were played key roles in abandonment of public industrial structure. ${ }^{21}$

Small production ateliers were removed in certain districts of istanbul depending on factors such as the increase of residential use, de-industrialization and rent increase. Loft examples began to be seen in Turkey -similar to loft living in the United States- through the move of designers and artists to these old factories.

The industrial revolution in Turkey, which began much later than Europe and America, is one of the most important reasons of differences in loft concept between these places. The loft concept in Turkey can be observed with a few individual examples in parallel with industrial development. This concept gained importance under the notion of 'loft style' and has recently become a type of essential luxury housing project. In this respect, the loft concept can be considered as a new concept compared to America and Europe. Examples in Turkey are luxury residences such as Levent Loft, Incity, Akfen Incek Loft projects, etc.

Loft-style structures are used for many different functions such as; house, atelier, art studio, office. Generally these structures are located in Beyoğlu, Karaköy, Beşiktaş and Üsküdar districts. ${ }^{22}$

Storage spaces of industrial structures, located in intercity spaces, are one of the most important reasons of the recent transformation in İstanbul. The rent increase of these structures because of residential needs is a factor that triggers transformation. The other important factor is that loft concept is an inspiration to many architectural projects. ${ }^{23}$ That is why loft concept has a promising future in Turkey.

\footnotetext{
${ }^{18}$ Bilgin, 1992

${ }^{19}$ Pamukçu, 2009.
}

${ }^{20}$ Pamukçu, 2009. $\quad{ }^{21}$ Köksal, 2005. $\quad{ }^{22}$ Taner, 2011. $\quad{ }^{23}$ Taner, 2011. 


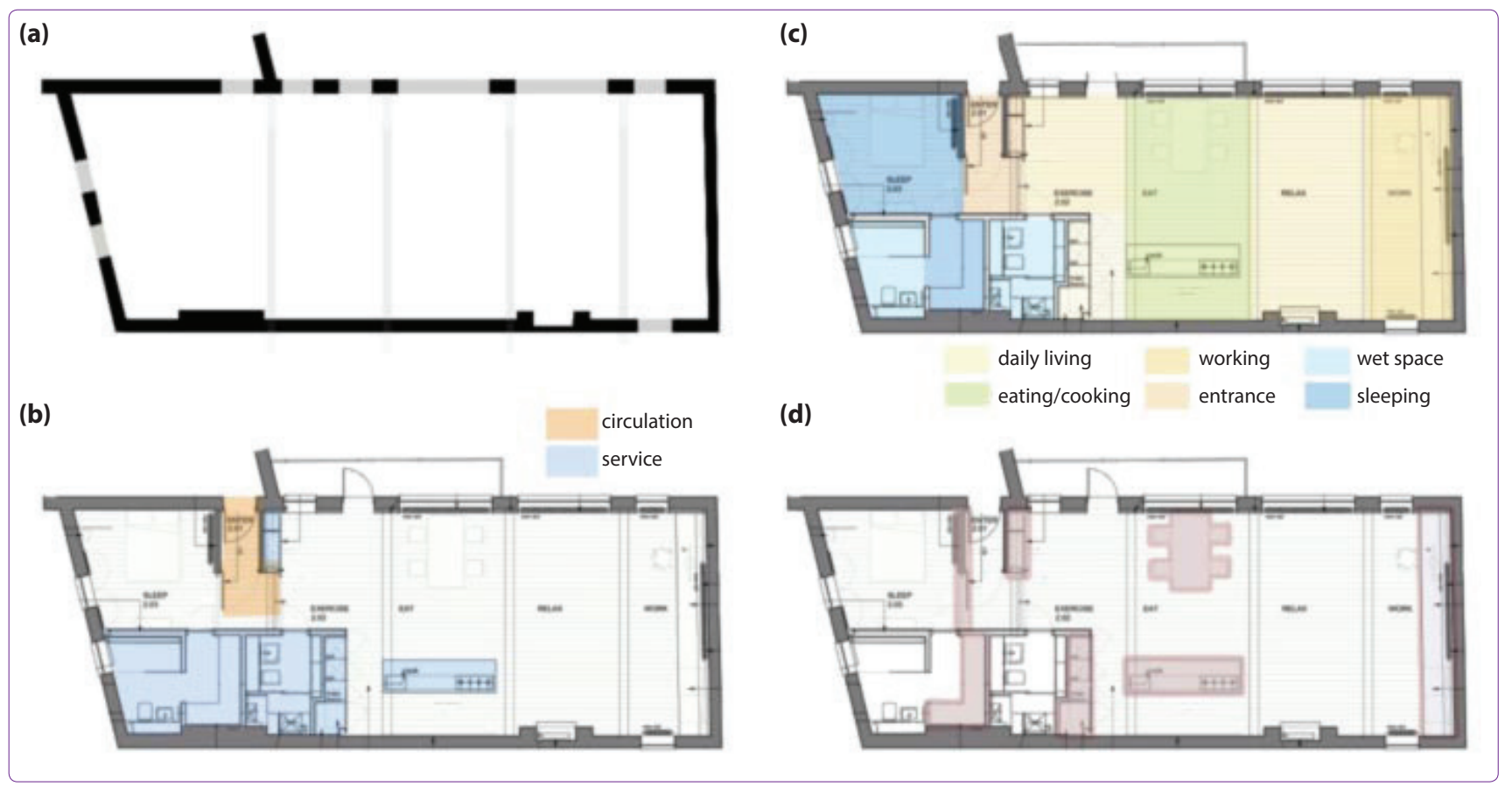

Figure 2. (a) Structure; (b) Service; (c) Spatial Organization; (d) Furnishing. (http://www.archdaily.com/481206/bermondsey-warehouse-loft-apartmentform-design-architecture)

There are few unused small-scale warehouses in Turkey for using them with original loft sense, while big-scale stores are considered appropriate for tourism purposes. At the beginning of the $20^{\text {th }}$ century, number of industrial structures existed in istanbul reduced from 256 to 42 because of various reasons. ${ }^{24}$ When transformation gained importance in the $21^{\text {th }}$ century, fortunately, the values of these remained structures were appreciated and some of them were registered.

In Turkey, there were many factories destroyed with the insufficient policies of the local government. These unconsciously realized urban transformation projects and destruction of the industrial heritage facilities indicate that industrial protectionism is not perceived as a concept in our country. Loft transformation is of considerable importance in terms of industrial heritage within the frame of architectural heritage and culture of old industrial buildings.

\section{Analyzed Examples}

\section{Examples from Abroad}

- Bermondsey Warehouse Loft Apartment, 2011

Previous Use: Warehouse Architect: FORM Design Architecture Location: London, UK Area: 104 sqm

\footnotetext{
${ }^{24}$ For further information about old industrial buildings in Istanbul, see: Taner, 2011.
}

Structure: The building itself was a single-floor warehouse. So, it has no load-bearing walls or columns inside, which is dividing the interior space. Its exterior walls are load-bearing and the beams passing the distance from one exterior wall to other transmit the load of the roof to those walls. As a result, the structural system provides maximum flexibility to the Bermondsey Warehouse Loft Apartment (Figure 2a).

Service: The service space containing storage, bathroom, and utility functions is comprised with the help of partition walls in the corner of the $17 \mathrm{~m} \mathrm{X} 6 \mathrm{~m}$ Loft. Adjacent to one of its partition walls, the closets of the cooking area are placed with a kitchen counter with cooking devices in the middle of the cooking area. Here, the cooking area is not separated from the main space of the loft (Figure 2b)

Spatial Organization: Except for the sleeping activity, the other activities like cooking, eating, exercising, relaxing, and working, all take place in the main space of the loft. There are no partitions, which define the borders of these different activity areas (Figure 2c)

Furnishing: As a furniture, only one closet has been used to determine the entrance space of the loft. None of the other furnitures were located with the purpose of characterizing the space for a specific activity. On the contrary, about the placement of furnitures, a special attention is paid not to obstruct the continuity of the interior space of the apartment loft (Figure 2d). 
- 95 King Street East Studios \& Loft, 2013

P.Use: Hardware Store Architect: Thier+Curran Architects Location: 95 King St., Canada Area: 1955 sqm

Structure: The building is a 3-storey ex-industrial building, which is over one hundred years old. Its exterior exposed brick walls are load-bearing and carry the building together with the steel columns and beams. The existing structure of the building is preserved. But, the wooden slabs are renewed and secondary steel columns are added in first and second floors. Those secondary columns in the middle of the floors are integrated with the partition walls of the one-bedroom loft apartments (Figure 3a).

Service: The building has a very complex system of service spaces. It's because of the art studios in the ground floor and basement, needing specialized washup areas and storages. In addition to hosting the cleaning and storing functions, the service spaces of the building play a key role to generate the horizontal and vertical circulation of the building. The staircases are located in between the service spaces of the building and some of the loft apartment typologies divided into subspaces through the arrangement of wet spaces (Figure 3b).

Spatial Organization: There is no variation in first and second floors, which hold the residential units of the loft building. The architect repeated the same spatial organization of the flats in both floors. But in one floor, there are two different flat typologies (Figure 3c).
Furnishing: Like the wet spaces used to separate the daily living and sleeping areas, the furniture, which is the closet, is also used for separation. But except for that, the other furnishing in the living and sleeping areas is arranged in the middle of those spaces, which are comprised with the placement of partition walls (Figure 3d).

\section{- The Loft of Frank and Amy, 2000}

P. Use: Factory Architect: Resolution 4 Architecture Location: Hell's Kitchen, New York, USA Area: 445 sqm

Structure: The loft apartment is located in a former industrial building and occupies an entire floor of the building. The building is carried by a prefabricated concrete column beam structure system. The columns are located along the exterior walls and along an axis passing through the middle of the floor area in the longitudinal direction. And that axis gives an important direction to the interior design of the whole loft apartment (Figure 4a).

Service: The service spaces of the building are located adjacent to a longitudinal exterior wall, which provides the vertical circulation in the building. And the service spaces of the loft, which includes the bathrooms and the kitchen, are placed around the structural axis in the middle of the apartment and also in between the building's service spaces. The service space of the loft, which is around the structural axis in the middle of the apartment, separates the public and

\section{(a)}

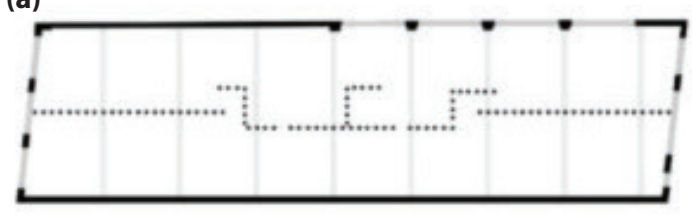

(b)

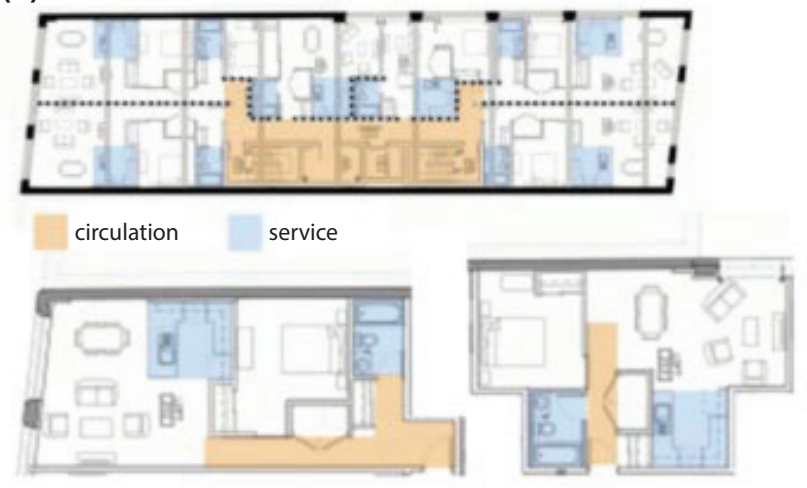

(c)

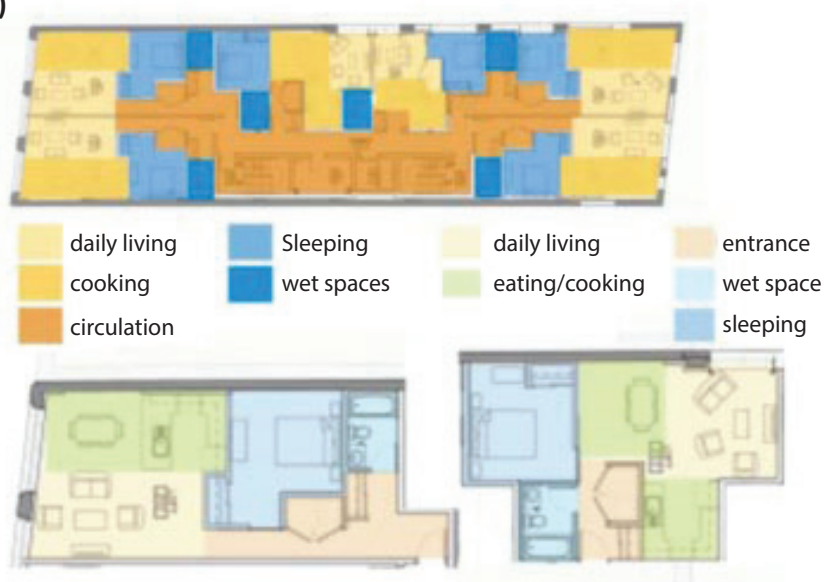

(d)

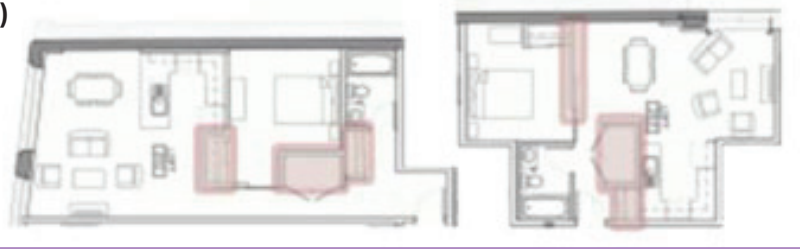

Figure 3. (a) Structure; (b) Service; (c) Spatial Organization; (d) Furnishing. (http://www.archdaily.com/479128/95-king-street-east-studios-and-lofts-thiercurran-architects/) 
private areas. While there is the sleeping area on one side of the service space, the daily living activities take place on the other side (Figure 4b).

Spatial Organization: The loft apartment is designed for an art critic and film editor and his family. It has three bedrooms and three bathrooms. While it serves as a house of a family, it also serves as an atelier of a film editor. In the main open space of the loft, the biggest area is dedicated to the playing activity to conduct workshops and to work. The main open space also offers place for cooking/dining, living and writing activities. The bedrooms are separated from the main space with sliding doors to close off bedrooms in need of more privacy, and to combine them with each other in need of more space (Figure 4c).

Furnishing: As the service spaces used to separate the public and private activities, the furnitures are also used for separation. The closets work together with sliding doors to determine the borders of differ- ent bedrooms. In addition to this, they also provide a changing room for the master bedroom and a transition space between the bedrooms and bathrooms (Figure 4d).

\section{Examples from Turkey}

\section{- Levent Loft, 2006-2007}

P. Use: Unfinished Office Building Architect(s): Tabanlıoğlu Location: Levent, Istanbul Area: 30,000 sqm

Structure: As shown in images, the structural system is consisted of reinforced concrete columns and beams and two service cores (vertical circulation units enclosed by reinforced concrete load-bearing walls). The system is located on the periphery of building plan. During transformation, concrete framed structure has completely preserved and the form and plan of the existing structure provides many advantages for flexible using (Figure 5a). Besides the structure, determining (a)

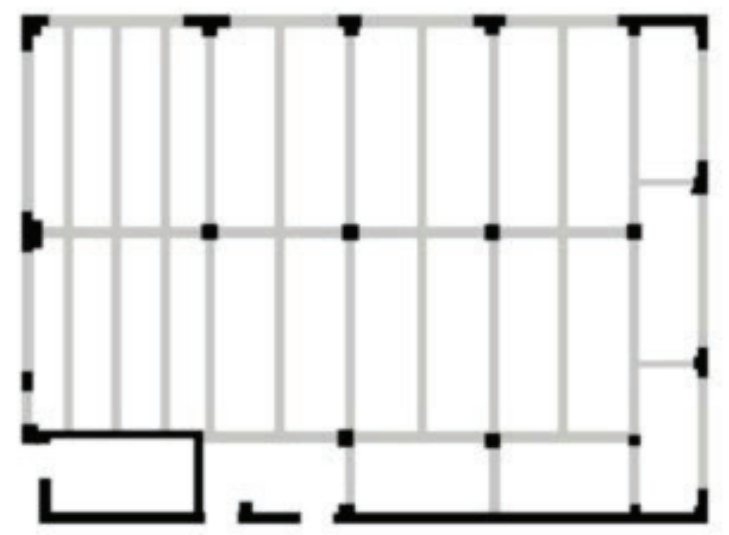

(b)

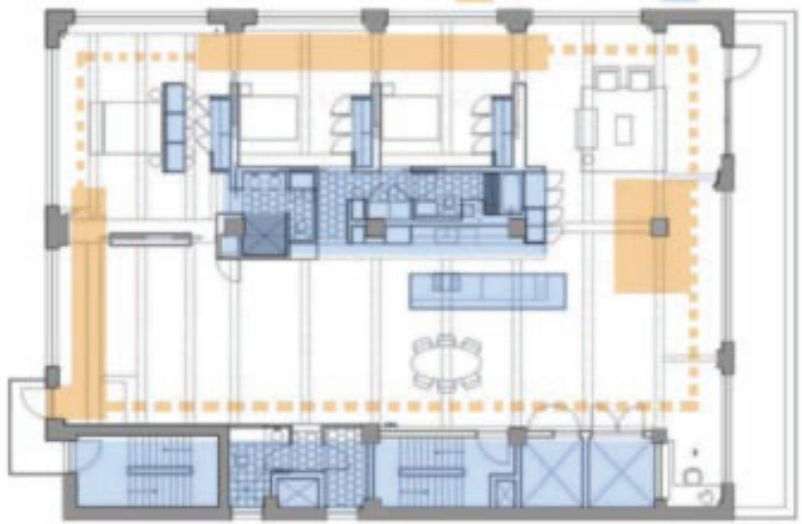

(c)

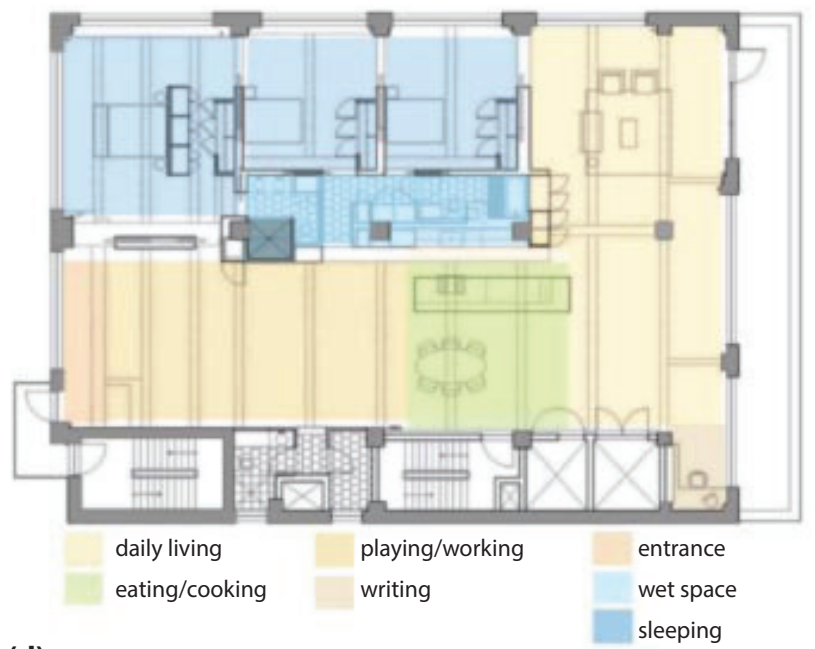

(d)

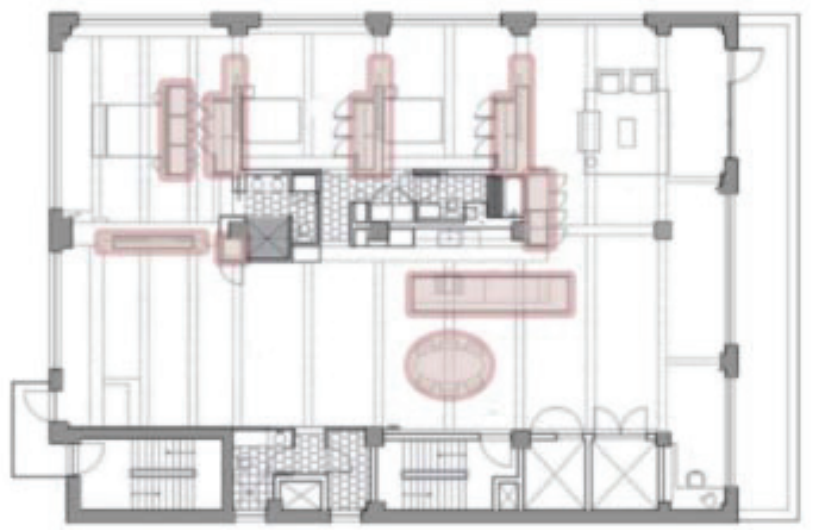

Figure 4. (a) Structure; (b) Service; (c) Spatial Organization; (d) Furnishing. (http://re4a.com/projects/loft-of-frank-amy/) 
(a)

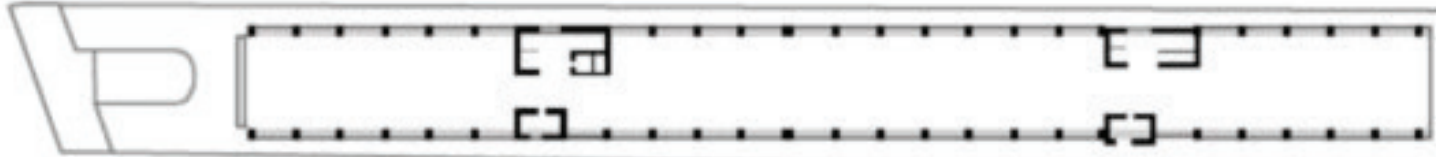

(b)

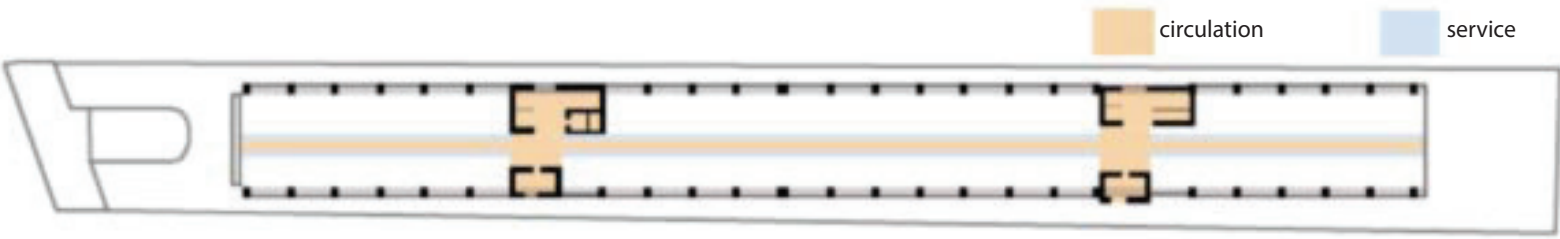

(c) \begin{tabular}{l|l|l|l} 
daily living & cooking & circulation & sleeping
\end{tabular}
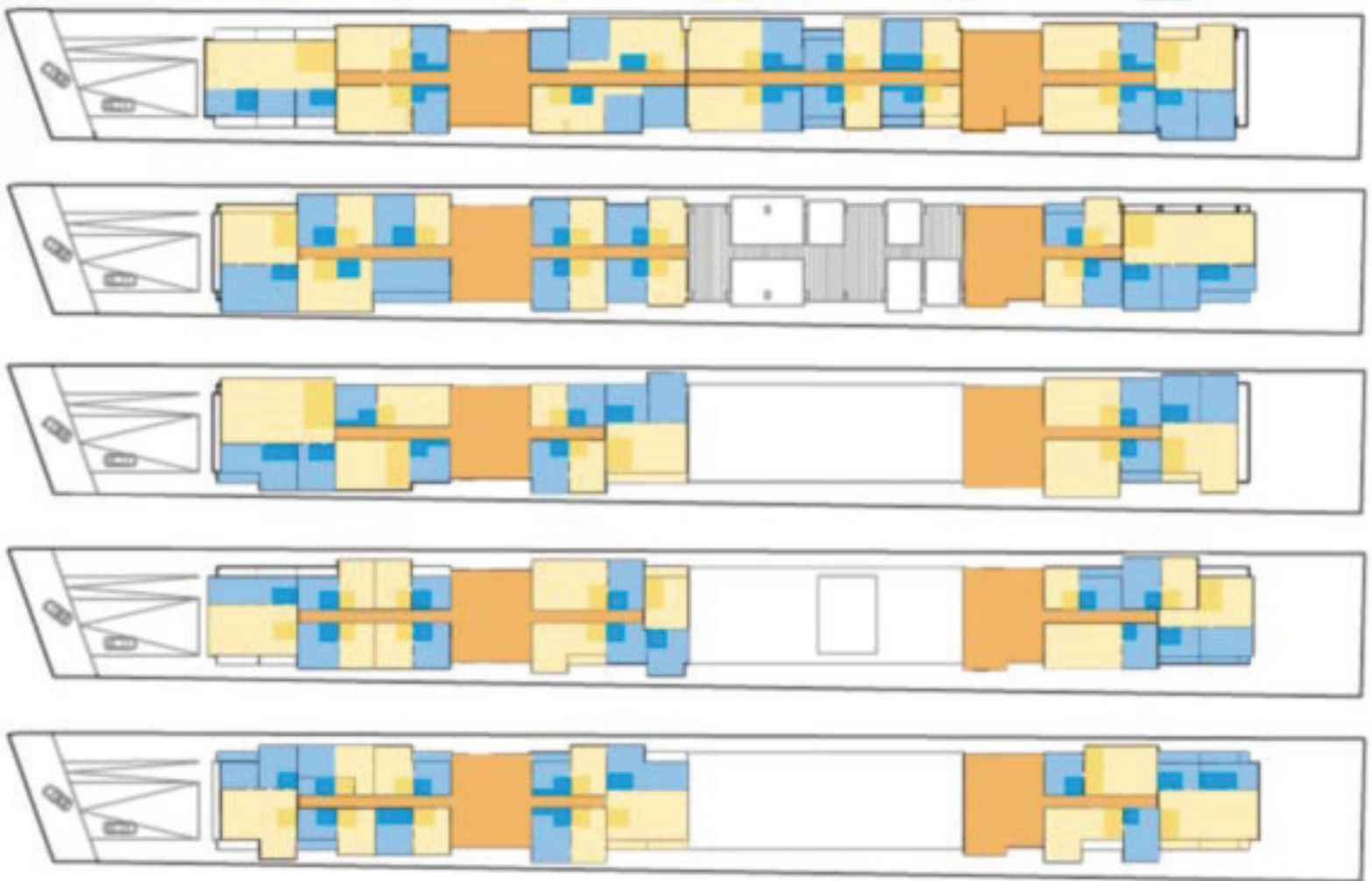

(d)

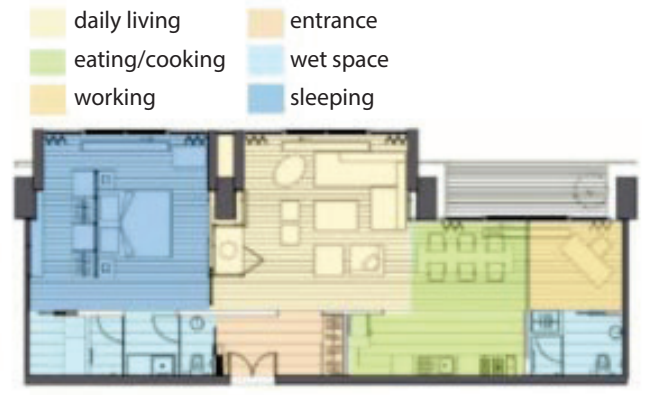

13 terraced $\mathrm{A}$

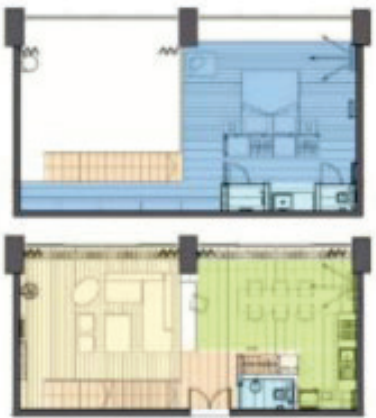

12.5 garden duplex

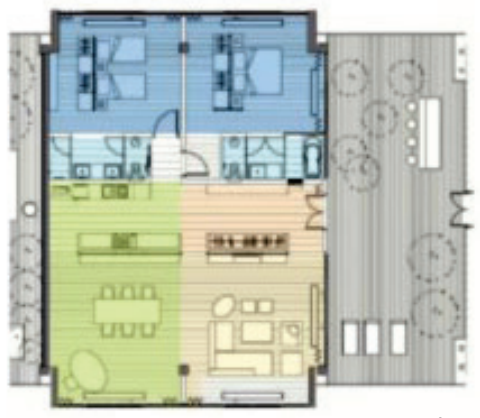

20.5 terraced

Figure 5. (a) Structure; (b) Service; (c) Unit Types. (d) Three different Unit Types and Spatial organization; In 13 terraced, the activities like daily living, cooking and eating take place in the main space of the loft. There are just two partitions as sliding doors. But they are not permanent or immobile components, so when users need more space, the solution is not using this dividers. If user opens their sliding doors, main area can be open space with its all volume without wet space. (http://www.archdaily.com/62092/levent-loft-tabanlioglu/) 
the linearity of the internal plans, the main spaces are indeterminate and it allows freedom in spatial organization. By way of retaining framed structure, the remarkable ceiling height compared to conventional housing's is preserved. This feature has differences on each floor. While it provides comfort in some flats, it contributes to diversity of spaces with mezzanine facilities in some other flats.

Service: There are two permanent cores in this building, which include vertical and horizontal access units. These cores are enclosed by load-bearing walls. Tabanlıoglu Architects designed a linear horizontal access corridor and service zone in the middle of the plan. Also, each unit's wet spaces (kitchen, bathroom) are located at each side of this linear corridor. Service spaces settled in a specific order as a linear band provides flexibility not only at the building scale, but also at the scale of residential units. Apart from permanent components, the rest of the building is open. There is no restriction for future using in wet spaces because of their changeable, adaptable facilities (Figure 5b).

Spatial Organization: Open spaces are not fanatically divided into sections, constitute a prospect to live-work and create at the same place; they are flexible and sometimes open to public. The loft units are of various sizes and types: the larger ones are duplexes with a terrace or roof garden. The architects offered choices to users by way of designing "modules". The span between the columns, which are located in the external surface, is 5.45 meters and it determines the width of a module. There are 21 various types of units with this idea of module. The basic one is composed of two or three modules. By adding one or half of modules to this unit, it is possible to obtain various units and different functions. User can change and easily enlarge the wet spaces or can also unite/divide the spaces within the unit itself according to his/her needs (Figure 5c).

In 13 terraced, the activities like daily living, cooking and eating take place in the main space of the loft. There are just two partitions as sliding doors. But they are not permanent or immobile components, so when users need more space, the solution is not using this dividers. If user opens their sliding doors, main area can be open space with its all volume without wet space.

Furnishing: Flats naturally have an industrial aesthetic with their un-plastered brickwork walls, exposed ductwork and concrete screed floors. Interior furnishing is not strictly determined by the architects. But, some storages and Tv units are positioned by them. Except that, users are able to adapt and change their units' interior configuration and furnishings. Also architects designed some separators as furniture. In 12.5 garden duplex type of plan, there is a bar placed between eating and daily living space, which provides spatial connection between these two spaces. This configuration has been interpreted in different ways in other types. In some units like 11.5, 20.5 terraced, wet spaces are located as a separator for dividing daily living and sleeping space. In 13 terraced, the component in front of the bearing column has a TV set and unit both in daily living space and in bedroom. This component not only breaks spatial relation from each other, but also link them. In the bedroom, movable room dividers double as storage space (Figure $5 \mathrm{~d}$ ).

\section{- Göksu Rope Factory Loft, 2010}

P. Use: Rope Factory Architect(s): A. Suyabatmaz, $H$. Demirel Location: Goksu, İstanbul Area: 35.000 sqm

Structure: The existing steel structure has been preserved with its original state. In structural terms, this building had sturdy with its structural technique and status. It was just recycled in order to use for the new construction. Raw wooden panels, natural wood and stone, steel and glass and various materials, which also are major materials of building, have been used with the aim of being in accord with the former identity of site. The characteristic roof section has not been altered and it provides natural air ventilation and daylight to the interiors. The facade together with the roof was designed as a loadbearing structure. The wooden panels also take place in creating second shell for the structure.

Service: This project is a residential complex and it is consisted of 40 individual units nearly. So every unit has their own service areas inside. Service spaces are composed of wet spaces and circulation areas. Especially one wet space is located in the entrance area of a unit and the other one is located in the sleeping unit. Because of the long and narrow spaces of building plan, horizontal circulation is linear from entrance to end of the unit (Figure 6). There is no restriction to use cooking space any time differently because it has adaptable facilities.

Spatial Organization: Factory buildings, which allow to product ropes, require very long and narrow spaces. Göksu Factory has responded to the necessity of these spaces with its volume by nature. The Architects' intention was to give equal pieces to users (like cutting rope in equal pieces). They gave a chance to users to adapt the spatial organization of their units according 


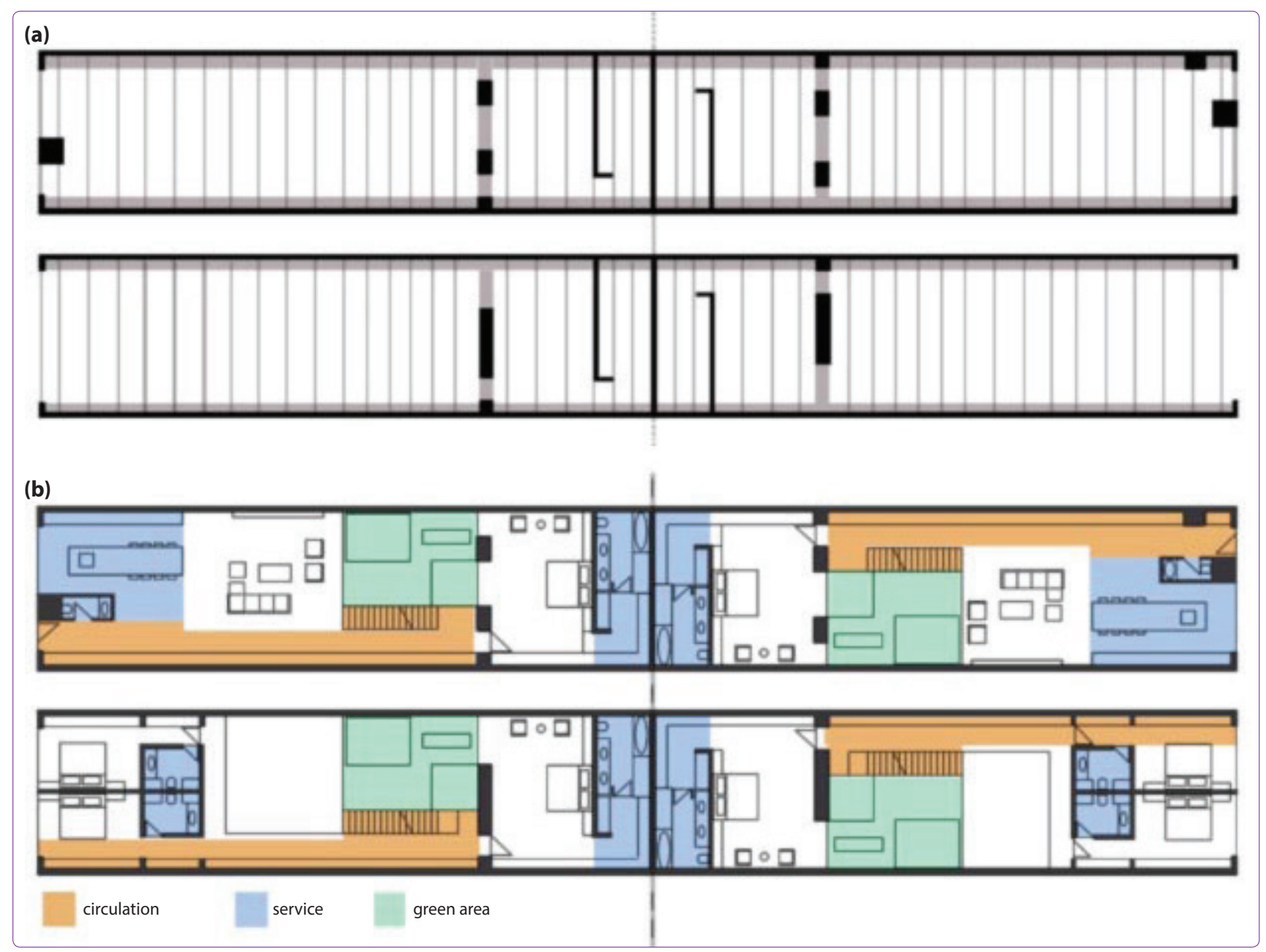

Figure 6. Loft flat named Type 3 (a) Structure; (b) Service. (http://www.archdaily.com/213866/goksu-rope-factory-lofts-suyabatmaz-demirel-architects/).

to their wishes by the way of these pieces. Apart from the structure, all the main area is open and indeterminate, especially on the entrance floor. In flat named type 3 , the sleeping and daily living area are separated from each other prominently. Daily living area has cooking, relaxing, sitting, reading and various activity areas without partitions. So they give a chance to users to adapt this place according to their wishes. They can use dividers to unite or divide spaces.

Furnishing: By the way of factory's volume-especially of its height- there are some types of flats that have galleries. It provides airiness and comfort to spatial configuration. The furniture unit, which is the longest side of rectangular planned flat, designed linear. This unit has been taken place as a tv set, shelves in daily living space, as countertop in kitchen and as dressing part in sleeping space. Also in this part, the library, which extends from the entrance floor to second floor, is noteworthy. Thus, liveliness is provided both in horizontal and vertical platform.

\section{- Misir Loft, 2002}

P. Use: Restaurant-Workplace Architect(s): Autoban Architects Location: Beyoğlu Area: 200 sqm

Structure: The structural system is composed of reinforced concrete columns and beams and one service core. As it is shown in structure image, except two columns, all structure system was located on the periphery of building plan. This structural design decision, which has taken years ago, also has appreciated by the Autoban Architects and they completely conserved the concrete structure. With the existing structure, users have flexible use in their flats because, the main free spaces are indeterminate and open and, this allows users to design their flat according to their wishes (Figure 7).

Service: Service spaces are composed of one main core, fire-escape and wet spaces. All of them are located on a specific area apart from flat's main space. Owing to this, the main space is open and all activities 


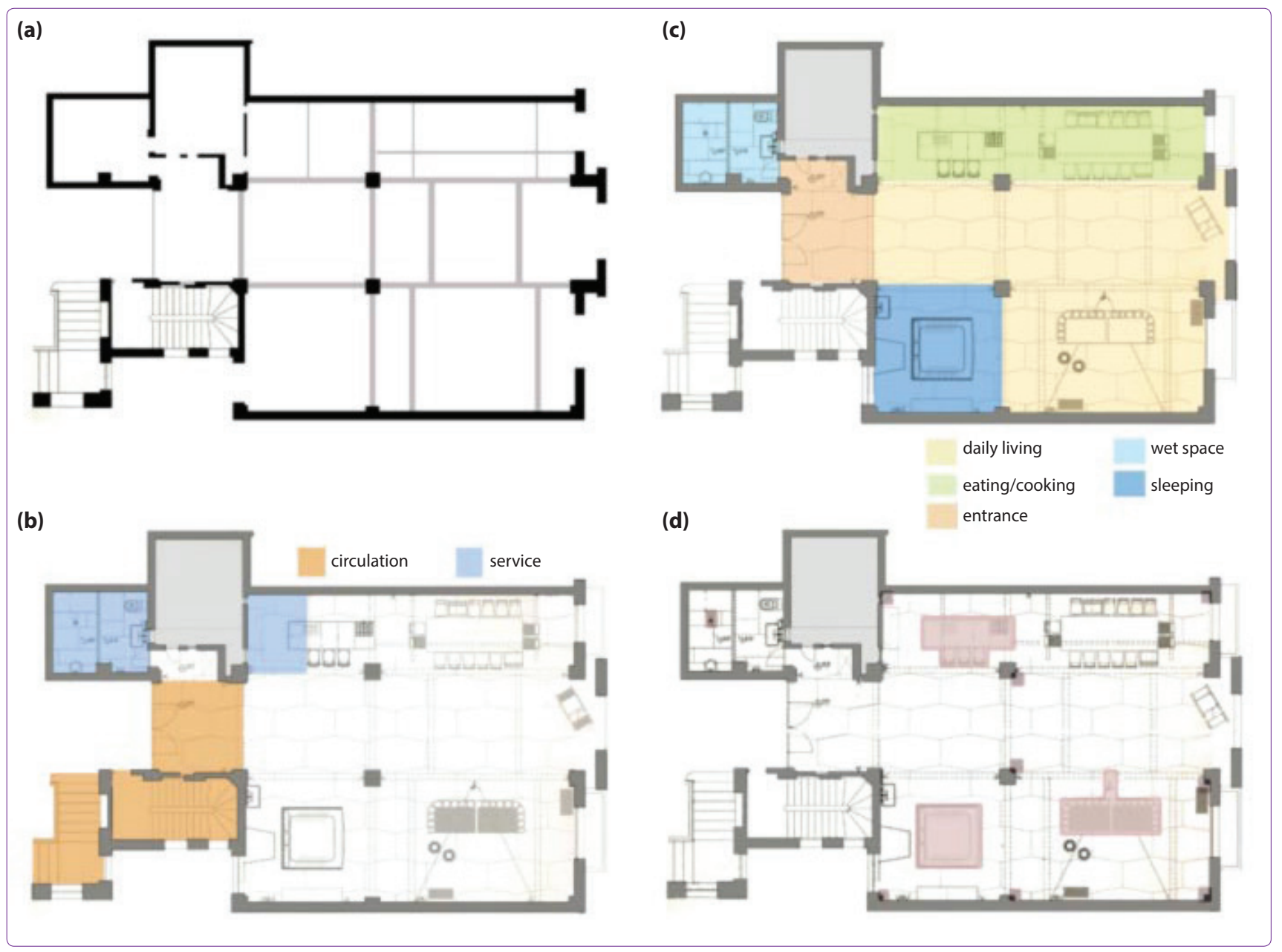

Figure 7. (a) Structure; (b) Service; (c) Spatial Organization; (d) Furnishing. (Mısır Loft, 2004. Tasarım Dergisi, vol.147, pp.132-139. Figures of case studies' analyses (Fig. 3-8) are edited by the authors. Last accessed date is 15.08 .15 for all web sources.)

can take place in one space without partitions. As it shown in images, bathroom has designed almost out of flat plan. Cooking and eating space was also being used as kitchen in old usage of flat. There is no restriction to use cooking space any time differently because it has changeable and adaptable facilities.

Spatial Organization: When the Architects met with the homeowner, they decided to design this flat as one-space loft. ${ }^{25}$ So they removed all the dividers in the main space. The flat is formed as only one space except bathroom. One column specifies sleeping space by completing to the square of structural scheme geometrically. The other one also specifies the cooking space by the same logic. In front of the entrance, the linear space between cooking and daily living spaces is unfurnished and it seems like a wide corridor access of the flat. And this makes this corridor as a space of any activity in any time. And all the main space seems like a multi-functional living space. The architects gave a chance to users to adapt the spatial organization of their units according to their needs and wishes. They can use their flat as a home, an office or a party place with small changes. ${ }^{26}$ They just need to unite or divide spaces by using some partitions and with this way they will have various types of life.

Furnishing: The flat has loft aesthetic concern with its off-form concrete columns and unconcealed ductwork. The Architects gathered all electric lines in a galvanized pipe, which is placed around all spaces in flat for decoration. When analyzing images, it is obvious that there is not much furniture in the flat. There is no TV set unit. Instead of that, there are slide projector and loudspeakers, which are placed around the daily living space. The wall in front of the couch is used in- 
stead of projection screen. In sleeping space, there is wheeled furniture that can move to every space in flat. It contains two functions in itself; upper part of it is bed (with ladder); below is laundry hanger.

Apart from these examples of Turkey, other loft buildings, which located mainly in Galata, Çengelköy and Hasanpaşa districts are listed below (Table 2).

\section{Conclusion}

As shown in analyzed loft examples, four topics (structure, service, spatial organization, furnishing) play an essential role for achieving flexibility in residential building. Owing to structural systems located on the periphery of building plan and determining the linearity of the internal plans, the main spaces are indeterminate and it allows freedom in spatial organization. Service spaces settled in a specific order as a linear band or enclosed with the load bearing walls in the middle of building provide flexibility because all sup- port unit elements (wet spaces, service core, access units) are gathered together. Flexible spatial organization in loft buildings allows users to change their flat according to their needs. Users can divide their units into the modules or join modules together. Besides off-form concrete columns and unconcealed ductwork has loft aesthetic concern in flat, correct choice of furniture also provides many advantages. In loft buildings, using not so much furniture in flat is important. Apart from this, furniture located as a separator for dividing certain units and some wheeled furnishings are appropriate to achieve flexibility.

As it is seen in this study, loft buildings embodying the characteristics of open building concept; which are adaptability, variability, and flexibility; have a huge potential to respond to the extreme dwelling production needs of urban environments. And although many of the ex-industrial heritages in Turkey were lost, there are still a remarkable amount of them waiting to be re-

Table 2. Lofts in Istanbul (edited by the authors)

\begin{tabular}{|c|c|c|c|c|c|}
\hline Name of place & $\begin{array}{c}\text { Year of } \\
\text { construction }\end{array}$ & $\begin{array}{c}\text { Year of } \\
\text { transformation }\end{array}$ & Previous use & Present use & Location \\
\hline Hasanpaşa Loft & $1950 \mathrm{~s}$ & 1987 & Carpenter's shop & Housing & Hasanpaşa \\
\hline Tanju Özelgin office & $1950 \mathrm{~s}$ & 1987 & Carpenter's shop & Housing & Hasanpaşa \\
\hline Filambarlari Design Office & $1750-60$ & 1993 & Port Hazelnut store & Design office & Çengelköy \\
\hline Dance studio & 20th century & 2002 & Philips Production Atelier & Dance studio & Galata \\
\hline Okay Temiz Rhythm Atelier & $1970-80$ & 2003 & Electrical shop & Atelier & Galata \\
\hline Bünyamin Derman Architecture Office & $1950-70$ & 2005 & Auto mechanic & Architecture office & Hasanpaşa \\
\hline Mimarhane & $\begin{array}{l}\text { The beginning } \\
\text { of the } 20^{\text {th }} \text { century }\end{array}$ & 2005 & Philips Production Atelier & Architecture office & Galata \\
\hline Mavra design café-workshop & 1900 & 2005 & Electrical shop & Design café & Galata \\
\hline Building Area Enginneering & $1950-60$ & 2006 & Electrical shop & Design atelier & Galata \\
\hline Mısırlı Ahmet Rhythm Atelier & $1970-80$ & 2007 & Electrical shop & Design atelier & Galata \\
\hline DDB office Salt Storehouse & $1840 \mathrm{~s}$ & 2008 & Storehouse & Advertising Agency & Kasımpaşa \\
\hline
\end{tabular}

Table 3. Advantages of Loft Conversions (edited by the authors)

Economics

Ecological Perspective

Socio-cultural Viewpoint
Instead of tearing down the dysfunctional and closed industrial buildings and constructing a new building in the same plot, these buildings and their new occupants can start to a living through the transformation of the same building fabric with a much less budget.

The re-function of existing building fabric provides far less greenhouse gas emission. In addition, masonry industrial constructions which were built in the last quarter of $19^{\text {th }}$ Century and in the early part of 20th Century in Turkey make a significant contribution to energy conservation of building with their construction materials and wall thickness. This feature of masonry industrial buildings makes possible to live in much better energy efficient buildings in comparison with the building to be constructed today.

The conditions and trends in Turkey, especially prevailing in our big cities, individualize people (also, isolate). This situation makes us think about that loft buildings will be in demand in the years ahead. However, how suitable for our usage and tradition is that individualization (isolation), is the question of another study. 
functionalized by its new investors. Many of the factories became unproductive and were left to decay. Up to now, ex-factories in Turkey have been utilized for nonresidential purposes except for some limited examples. There are many small ex-industrial buildings or ateliers converted into loft apartments as it is also illustrated in the previous chapter. The increasing residential needs and existing dis-functionalized building stock of Turkey show that re-utilizing the existing building stock as dwelling can have numerous advantages (Table 3 ).

\section{References}

Bilgin, ì. (1992) Konut Üretiminin Karşılaştırılmalı Analizi, YUMFED Publications, Istanbul.

Çetin, D.F. (1999) "Fizik Tedavi ve Rehabilitasyon Ünitelerinde Değişen Kullanıcı Gereksinimlerine Bağıı Esnek Tasarlama Faktörlerinin Belirlenmesi", Phd Thesis, YTU, Institute of Science, Istanbul.

Deniz, Ö. (2003) "Çok Katlı Konutlarda Değişebilirlik sağlama stratejisi: 'Yapı Elemanlarının hiyerarşik organizasyonu' yaklaşımı", Tasarım-Kuram Journal, vol.3/may, pp.115129.

Habraken, J. (1972) Supports, An Alternative to Mass Housing, Urban International Press, UK.

Habraken, J. (2008) Design for Flexibility, Building Research \& Information, 36 (3), 290-296.

Hudson, J. (1987) The unanticipated city, Amherst: University of Massachusetts Press.
Huyssen, A. (2006) Introduction: Modernism after Postmodernity, New German Critique, 33(3 99), pp.1-5.

Köksal, T.G. (2005) “istanbul'daki Endüstri Mirası için koruma ve yeniden kullanım önerileri", PhD Thesis, Istanbul Technical University, Institute of Science, Istanbul.

Pamukçu, K. (2009) "Ticari ve endüstriyel yer değiştirmenin sonucu olarak; "loft" mekânlarının değerlendirilmesi", Yildiz Technical University, Master Thesis, Institute of Science, Istanbul.

Russell M. (1978) "At home in a French Factory", New York Times Magazine.

Taner, S. (2011) "Re-functioning the industrial buildings of Istanbul within the framework of 'loft' concept", Istanbul Technical University, Master Thesis (Adv: Prof. Dr. Yurdanur Dülgeroğlu Yüksel), Institute of Science, Istanbul.

Tapan, M. (1972) Prefabrike Elemanlarla Yapımda Esneklik veya Değişkenlik Sorunu, Yak Bulletin, ITU Department of Architecture, Istanbul.

Üstün, B. (2000) "Konut Tasarımında Esnek Planlama Amaçlı Yaklaşımlar ve Tasarımda Kullanıcı Katılımının Öneminin Eskişehir Örneğinde İncelenmesi", MSU, Phd Thesis (Adv: Prof. Dr. Esad Suher), Istanbul.

Yürekli, F. (1983) Mimari Tasarımda Belirsizlik: Esneklik/ Uyabilirlik İhtiyacının Kaynakları ve Çözümü Üzerine Bir Araşttrma, ITU Department of Architecture, Istanbul.

Zukin, S. (1989) Loft Living: Culture and Capital in Urban Change, Rutgers: Rutgers University Press.

URL. 1. http://www.artdecor.com.tr/icmimari/00383/?print erfriendly=yes [Erişim Tarihi: 14.03 .2015$]$ 